\title{
Problems of the development of the banking sector after the pandemy
}

\author{
Fedor Buraev ${ }^{1}$, Marina Danilina ${ }^{1,2,3,}$, Elena Kostromina $^{4}$, and Anna Silaeva ${ }^{4}$ \\ ${ }^{1}$ MUIV, Moscow University imeni S.Yu.Witte. Moscow, Russia \\ ${ }^{2}$ Finance University under the Government of the Russian Federation, Russia \\ ${ }^{3}$ Russian Economic University, Russia \\ ${ }^{4}$ Russian State University of Tourism and Service, Moscow region, Pushkinskiy rayon, dp. \\ Cherkizovo Russia
}

\begin{abstract}
The coronavirus pandemic has negatively impacted the global economy. The banking sector is no exception. The authors analyze the impact of the coronavirus on the functioning and subsequent development of the banking sector in Russia. If we consider this pandemic as a one-time event, then the banking system will recover quickly enough, and there will be no tragic long-term consequences. However, if we talk about the coronavirus pandemic as a recurring event that will occur at intervals of two or even three times a year, then the real consequences are still difficult to assess.
\end{abstract}

\section{Introduction}

The problems of the banking system are largerly discussed $\mathrm{n}$ the analytical articles of many researchers? For example, in $[1,2,3,4]$. In this article we will focus on the problem of the development of the banking sector after the pandemy. The Russian banking sector is confidently going through this year, despite all the restrictions that the fight against coronavirus demanded. Large banks were able to improve their position and grow their business. The locomotive of the loan portfolio growth was the mortgage, but the industry's net profit by the end of 2020 was expected to decline.

During the pandemic, large banks showed stable business dynamics and strengthened their positions. In April - August, their loan portfolio grew by 4\%, while the dynamics of other banks was negative.

The cost of risk of the top 30 banks in the first half of the year was lower than that of the rest of the industry: $2.6 \%$ versus $3.3 \%$. As a result, the drop in the return on equity (ROE) of the largest banks turned out to be less noticeable, and in terms of its absolute values, they are almost twice ahead of banks outside the top 30 .

The business performance of the 30 largest banks increased in the first half of the year. Despite the decline in overall ROE, they improved their profit margins before deduction due to improved net interest margins and operational efficiencies.

\footnotetext{
${ }^{*}$ Corresponding author : marinadanilina@yandex.ru
} 
The main reason for the decline in profits of the banking sector in 2020 was the growth of reserves, said Olga Ulyanova, Vice President of Moody's. But this growth was largely offset by an increase in net interest and commission income, she points out, as lending increased in 2020.

In particular, a significant amount of fee and commission income is generated due to new loans issued, in addition, the growth of transaction activity had a positive effect on them. In the context of the pandemic and the lockdown, Russians began to use cards for payments more often instead of cash, which led to an increase in income from acquiring.

\section{Materials and methods}

The authors used content analysis in order to determine the main trends of the banking system in the last years. Pandemic has created new conditions for the banking system's functioning.

The self-isolation regime due to the pandemic has allowed banks to actively take digital products and services to a new level. VTB was the first Russian bank to issue an online mortgage, after which it created a completely remote format for buying a car. By the end of this year, the bank plans to scale the new service across the country.

During the pandemic, VTB provided customers with additional remote services. Among them, for example, the opportunity to become a client of VTB remotely using biometrics, to seek advice in the chat and Viber messenger, to issue a digital card. In addition, the bank continued to serve clients with an expired passport and VTB bank card, extended the lease of cells without fines and penalties, and increased the limits of money transfers in VTBOnline.

To expand the opportunities for Moscow residents to purchase a Troika card without a queue for travel by public transport, VTB began issuing cards in all Moscow offices.

As part of support measures for customers affected by the spread of COVID-19, the bank made it possible to connect credit holidays for individuals with an increased limit (mortgages, car loans, cash loans, credit cards). The bank accepts applications for their provision through a chat bot in VTB-Online.

During the pandemic, the activity of digital channels among the bank's clients increased significantly. The number of sessions at VTB-Online in March increased by one third compared to the previous month. Now the VTB-Online application is used by more than $60 \%$ of the bank's clients, the share of remote settlement transactions is approaching $100 \%$, more than $99 \%$ of brokerage business transactions are carried out in online channels.

Even before the introduction of self-isolation, up to $60 \%$ of savings products were opened online; in April, the share of registration of savings products through remote channels increased even more. At the same time, in April compared to March, we note an increase in the share of online applications for mortgages by $9 \%$, for cash loans - by 1.5 times, for car loans - by $60 \%$.

Raiffeisenbank has long relied on technological development and is actively developing remote banking channels. In 2019, the bank's customers began to use online channels $60 \%$ more often. $50 \%$ of loans are issued with the participation of a mobile bank.

Almost $80 \%$ of deposits and savings accounts are opened by customers using Raiffeisen-Online. In a pandemic, the goals remain the same: to allow clients to manage their finances - to perform all the necessary operations, order banking and insurance products - wherever it is convenient.

Mobile applications have been and will remain the most promising area of development and "banking products". This is an important channel for clients to register and receive banking products, which could not be overlooked either before the pandemic or after. It 
should be noted that young people (up to 35 years old) use mobile applications much more often.

Users always put forward two basic requirements for banking products and communications with banks: benefit and security. Next comes the convenience and quality of service, but these are already specific characteristics for people of different ages and incomes. If a person has even the slightest doubt about the first two factors, he simply will not be served at the bank.

Daily banking remains a key area of development of the mobile RBS channel in the current environment. According to statistics, the majority of people serviced at different banks are ready to completely switch over time to remote service (unless, of course, they consider it more profitable and secure than offline banking). And a little more than half are ready to open their next product in Internet Banking / Mobile Banking.

In the current environment, the quality of customer service directly depends on the quality of the banks' mobile applications. The more innovative technologies it uses, the more often it is updated and improved, the higher the bank's competitiveness in a pandemic.

The first year of the pandemic, the banking sector was relatively painless, experts say. At the same time, the problems of the sector tend to accumulate, so the next year is fraught with many risks and uncertainties for financial market players and their clients.

The main attention of the banking sector in the coming year will be focused on the quality of loan portfolios, said Mikhail Doronkin, Managing Director of the NKR Rating Agency. Today, a significant part of the sector's problems are not reflected in the reporting due to the large volume of restructuring and easing of the Central Bank on provisioning. According to NKR forecasts, up to $15-20 \%$ of all borrowers whose loans have been restructured will not be able to return to the payment schedule, which will entail an increase in overdue debt in the sector next year.

The explosive growth of mortgage lending against the backdrop of record low rates and preferential home lending programs caused many questions this year. However, most of the experts interviewed do not see the threat of a bubble formation in this market in 2021 . According to Valery Piven, Senior Director of the ACRA Financial Institutions Ratings Group, the mortgage market will continue to grow next year. "Preferential mortgages at low rates are not a prerequisite for market growth. Even if the program is curtailed, market growth can support the recovery of real incomes of the population," he admits.

The completion of the preferential mortgage program for new buildings in July next year will certainly affect the dynamics of loans, Doronkin said. After the end of the state program of preferential mortgages, the market should be ready for a decrease in demand in the primary market, agrees board member - Rosbank's retail business director Alexei Lola.

At the same time, market participants expect a reorientation of demand from new buildings to the secondary market.

Another challenge for banks is associated with the outflow of funds from time deposits due to low rates and the introduction of personal income tax on interest on deposits. In the first half of 2021, this outflow may continue (about 0.5-0.7 trillion rubles), including against the background of the uncertainty of the effect of the "tax on deposits", but in the second half of the year, part of the cash held on hand will return to deposits and accounts (0.7-0.8 trillion rubles), says Nadezhda Karavaeva.

Another big problem for the next year is the adaptation of the banking business to the new digital reality, says Gennady Salych, Chairman of the Board of Freedom Finance Bank. "More than a third of the market is now concentrated on the Internet, and these are completely different mechanisms of competition for a client than classic calls, billboards, brochures, etc.," he notes.

The massive transition to digital channels is forcing customers to give preference to those banks that are already leaders in mobile and Internet banking, and this may lead to a 
further reduction in the number of small and medium-sized banks, warns the head of research at the Center for the Study of Financial Technologies and Digital Economy at Skolkovo-NES Egor Krivosheya.

\section{Results}

The analysis showed that the Russian banking system turned out to be much better prepared for this crisis than for all previous ones. Everything that has happened to banks in recent years - including the actions of the Bank of Russia to cleanse the system of weak and unscrupulous players - has allowed banks to approach this crisis in the best possible historical form. For several years, the real capital of banks has grown very strongly. Also, at the time of this crisis, banks did not have any liquidity problems. Of course, the regulator was ready to introduce additional measures to support liquidity, if they were necessary, but this was not required.

At the same time, public finances in the country as a whole turned out to be at their best: we have no debt from the state, the budget is in good condition. Also, in contrast to past crises, we are not seeing an increase in the key rate in Russia, but its active decline. What does this mean for our borrowers? They will be able to get cheaper refinancing, will be able to lengthen their loans and refinance them at lower rates. All this ultimately leads to the fact that their credit quality will increase. Of course, for the banking system as a whole, a decrease in the rate reduces the opportunities to earn money. However, in times of crisis, this is a boon for clients, which also has a positive effect on banks.

The measures of support introduced by the government in our country were different from those of America or Europe - we did not scatter "helicopter" money, but at the same time the measures were quite precise and timely. For example, the state mortgage program at a rate of $6.5 \%$ has led to the fact that today the opportunity to improve housing conditions has become the most affordable for citizens in recent years.

Apartment prices have not changed and probably even increased a little, but due to the rate cut due to the state program, the cost of debt service has become significantly lower, and the number of potential borrowers who have become available to purchase housing on a mortgage has seriously increased. This is very helpful for the housing market and the banking sector.

The state also introduced direct cash subsidies, for example, to support employment. The payroll loan program and further loan write-offs while maintaining employment have become very significant support for many SMEs. This measure is highly demanded and effective.

Thus, if we consider this pandemic as a one-time event, then the banking system will recover quickly enough, and there will be no tragic long-term consequences. However, if we talk about the coronavirus pandemic as a recurring event that will occur at intervals of two or even three times a year, then the real consequences are still difficult to assess.

\section{References}

1. Amel-Zadeh, A. and G. Meeks. Bank failure, mark-to-market and the financial crisis. Abacus 49(3): 308-339. (2013).

2. Badertscher, B. A., J. J. Burks and P. D. Easton. The market reaction to bank regulatory reports. Review of Accounting Studies 23(2): 686-731 (2018).

3. Barton, D., D. Carey and R. Charan. One bank's agile team experiment. Harvard Business Review (March/April): 59-61. (2018).

4. Harvard Business Review. How the great recession changed banking. Harvard Business Review (March/April): 26. (2018). 